\title{
Susceptibility of soil to wind erosion in arid area of the Central Rift Valley of Ethiopia
}

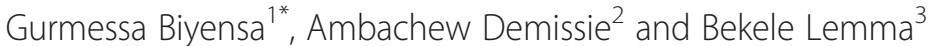

\begin{abstract}
Background: In Central Rift Valley (CRV) of Ethiopia, renewable land resources are under pressure. Acacia woodland clearance, frequent cultivation, crop residue removal and mono-cropping are among the major land mis-management practices in the area. This has largely been affecting the soil quality. The current study is aimed at assessing the impact of Acacia woodland conversion, and the subsequent mis-managements on selected soil physical properties, and their relation to the prevailing wind erosion in the area. For this study, four land use/land cover types, namely protected woodland (PWL), managed pastureland (MPL), parkland agroforestry (PAF) and treeless cropland (TLCL) were Considered.

Results: Higher $(P<0.001)$ macro-aggregates $(>0.25 \mathrm{~mm})$ fraction of soil was found under PWL and MPL while higher fraction of micro-aggregates $(0.053-0.25 \mathrm{~mm})$ of soil was found under PAF and TLCL. Soil under PAF and TLCL had higher $(P<0.001)$ proportion of aggregates of $<1 \mathrm{~mm}$, implying potential susceptibility of the soil to wind erosion. Higher soil bulk density (BD) was found in the most top layer $(0-15 \mathrm{~cm})$ of TLCL and PAF, and this could be attributed to the trampling effect by animals freely released to these land use types.

Conclusion: In the study area, conversion of native woodland to PAF and TLCL and the subsequent mismanagements negatively affected some soil physical properties, thereby enhancing severity of soil erosion by wind. In contrast, although not commonly practiced by smallholder farmers, soil under MPL is more stable and less susceptible to wind erosion.
\end{abstract}

Keywords: Andosols; Dry aggregation stability; Land degradation; Crop residue removal

\section{Background}

Soil physical properties could be affected not only by land use changes but also by land management practices (Liu et al. 2006; Snyder et al. 2009; Alberti et al. 2010; Rouw et al. 2010). Soil compaction may occur under cultivated lands due to intensive cropping, short crop rotation, and inappropriate soil management (Quirogaa et al. 1999; Hamza and Anderson, 2005). Bulk Density (BD) is found to be decreased significantly in the order of no - tillage > manual tillage $>$ plough - plough tillage $>$ plough - harrow (Osunbitana et al. 2005).

Another important factor affecting soil physical properties is livestock trampling. Releasing cattle to cultivated land for foraging was reported to cause soil compaction (Hamza and Anderson 2005). This affects associated soil physical properties such as BD,

\footnotetext{
* Correspondence: b.gurmessa@cgiar.org

${ }^{1}$ International Center for Tropical Agriculture (CIAT), clo International

Livestock Research Institute (ILRI), Addis Ababa office, Addis Ababa, Ethiopia Full list of author information is available at the end of the article
}

infiltration, and porosity (Siri-Prieto et al. 2007). It significantly increases soil BD and decreases porosity in the upper soil profile (Binkley et al. 2003; Chaichi et al. 2005; Curran-Cournane et al. 2010) and under similar soil type (Martínez and Zinck 2004; Sharrow 2007). The premise behind is that cattle can exert pressure up to $0.2 \mathrm{MPa}$ (Mega Pascal), which is significantly greater than the pressure exerted on the soil surface by tractors, which can vary from 0.03 to $0.15 \mathrm{MPa}$, and this may lead to soil compaction; which in turn could increase BD (Proffitt et al. 1993). But, the impact is mostly pronounced in the topsoil (Proffitt et al. 1995). This in turn results in loss of pasture production and quality (Hamza and Anderson 2005).

However, there may be variation even among stock types like cow, sheep and goats (Curran-Cournane et al. 2010). In Lar-rangeland, Iran, Chaichi et al. (2005) assessed impact of grazing on soil $\mathrm{BD}$, and reported that it was higher in the upper layer $0-15 \mathrm{~cm}$ than in the $15-$ $30 \mathrm{~cm}$. However, to detect such a significant difference 
in these soil physical properties, the land has to be allowed to grazing for longer period of time. For example, an experiment conducted by Radford et al. (2008) in Central Queensland, on change in soil physical properties after a land had been allowed to grazing for a short period of time did not show any significant difference.

Dry aggregate stability is one of the most important soil physical parameters that are used to estimate erosion susceptibility of soils (Greeves et al., 2007). On the other hand, soil aggregate stability is a function of different soil management factors such as tillage frequency (Masri and Ryan 2006), intensity of grazing (de Souza et al. 2010) and land use change (Gajić et al. 2013). Loss of soil aggregate stability could enhance soil erodibility. Susceptibility to erosion goes higher as aggregate size of soils decrease. The macro-aggregates that are characterized by higher SOC and N (Wilson et al. 2009) are less susceptible to wind erosion than the micro-aggregates (Yang et al. 2007). However, the macro-aggregates are more prone to management impacts (Ashagrie et al. 2007). This implies that poor land management options deteriorates these macro-aggregates, and leads to soil erosion.

Land degradation, a result of land miss-management practice, is commonly observed in Central Rift Valley (CRV) of Ethiopia. Among all, Acacia woodland conversion to different land uses is the most common practice in this area. On the other hand, the Acacia are the main means of livelihood for the rural economy of the area. This is sometimes reflected by the use of these trees for fuel wood, fodder, nitrogen fixation, and shade (Getachew and Ståhl 1998). In spite of its environmental, ecological and socio-economic importance, it has been under pressure (Getachew and Ståhl 1998; Jansen et al. 2007; Yimer and Abdelkadir 2010). Following the conversion, some common land uses, which have been conventionally managed, have evolved.

A few studies have been conducted on the impact of cultivated and grazing lands, without distinguishing between cultivated land with trees and cultivated land without trees, on soil properties. These studies have also not considered the alternative land use option to free grazing, the managed pastureland (MPL). The current study is therefore aimed at evaluating the impact of the two distinct conventional farming systems, the TLCL and the PAF as well as the MPL on BD, porosity, moisture content $(\mathrm{MC})$ and aggregate stability.

\section{Methods}

\section{Site description}

This study was conducted in the Central Rift Valley (CRV) of Ethiopia (Fig. 1). The area receives an average annual rainfall of $760 \mathrm{~mm}$ (Fig. 2). The mean monthly temperature varies from $18.5{ }^{\circ} \mathrm{C}$ to $21.6{ }^{\circ} \mathrm{C}$ with mean annual temperature of $20{ }^{\circ} \mathrm{C}$. The soil type of the study site is Haplic Andosols, Typic Haploxerands (Zewdie 2004; Itanna 2005), and it is of sandy loam texture. The vegetation of the area is characterized as tropical savannah (Getachew and Ståhl 1998) dominated by Acacia species, shrub and bushes. Acacia trees are dominant and important means of livelihood for the local people.

Land uses considered for the study were parkland agroforestry (PAF), treeless crop land (TLCL), Managed pastureland (MPL) (Fig. 3c) and protected woodland (PWL). The MPL is practiced in Adami Tulu Agricultural Research Center (ATARC) (Fig. 3d). But, this practice is confined to the large compound of the center, and is rarely practiced by the smallholder farmers. Crop residues are continuously removed from the PAF and TLCL to feed Livestock during the dry season. These two land use types were formed 25 years ago, and have been cultivated for this long time without fallowing. Mono-cropping (for up to 10 years) is commonly practiced under the PAF and TLCL. During the dry season, it is common to see wind erosion on these two land uses (Fig. 3b). In this area, crop residue is regularly removed for animal feed soon after crop is harvested (Fig. 3a). Cattle are freely released to the croplands before and after the cropping period. Herd of Camels of the semi-pastoralists is also freely released into the evergreen Cacti, which are found on the boundaries of land parcels and look green, and which are mostly the main source of feed for camels during the dry season.

\section{Sampling and laboratory analysis}

The PWL was used as a reference since the other land uses were formed by converting this land use type. The design was pseudo-completely randomized design with three replications. Per replicate, five $20 * 20 \mathrm{~m}$ random plots were considered. Soil samples were collected at the center and four corners of each plot along the soil depth of $0-15 \mathrm{~cm}, 15-$ $30 \mathrm{~cm}, 30-45 \mathrm{~cm}$ and $45-60 \mathrm{~cm}$ using riverside auger. Hence, a total of 100 samples ( 5 samples $\times 5$ plots $\times 4$ depths) were collected for each replicate. Then, the 25 samples from each respective depth range were thoroughly mixed, and one composite soil sample weighing $1 \mathrm{~kg}$ was taken. A total of 48 (3 replicates $\times 4$ depth range $\times 4$ land use) composite soil samples were taken to the Zeway Soil Testing Laboratory for the analysis of texture, gravimetric moisture content $(\mathrm{MC})$ and porosity $(\mathrm{P})$. Additionally, nine separate core samples were taken from the middle of each of the $20 \times 20 \mathrm{~m}$ random plots for bulk density (BD) analysis at the depth ranges of $0-15 \mathrm{~cm}, 15-30 \mathrm{~cm}, 30-45$ $\mathrm{cm}$ and $45-60 \mathrm{~cm}$. Then, a total of 540 core samples i.e. (9 sample $\times 5$ plot $\times 3$ rep $\times 4$ land uses) were collected. From each of the $20 \times 20 \mathrm{~m}$ random plots, a total of 300 i.e. ( 5 samples $\times 5$ plot $\times 3$ rep $\times 4$ land uses) undisturbed soil samples were collected from the top 0-15 cm depth 


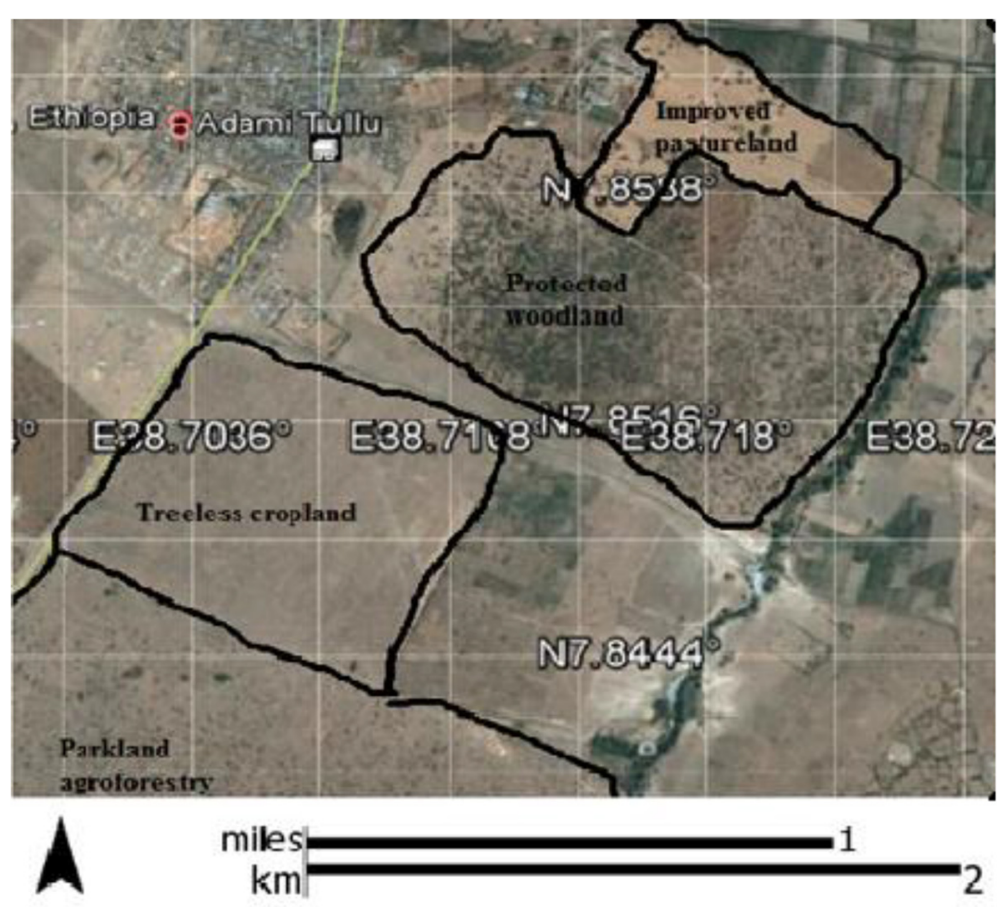

Fig. 1 Map of the study area showing the land uses considered for the study

only for dry aggregate stability test. All the five samples per plot were composited to one sample with little disturbance, and only 60 ( 5 sample $\times 3$ rep $\times 4$ land use $)$ samples were taken for sieving.

Soil texture was estimated using Hydrometer method. Samples were oven dried at $105\left({ }^{\circ} \mathrm{C}\right)$ for $24 \mathrm{~h}$, and BD was calculated as oven dried mass per core volume.
Gravimetric moisture content was calculated as the ratio of weight of water to weight of oven dry soil. It is a weight fraction calculated as subtracting weight of oven dried soil from initial fresh sample weight divided by dry weight of the sample. Following the methods described by Hao et al. (2008), for dry aggregate stability estimation, each undisturbed sample was air dried for seven

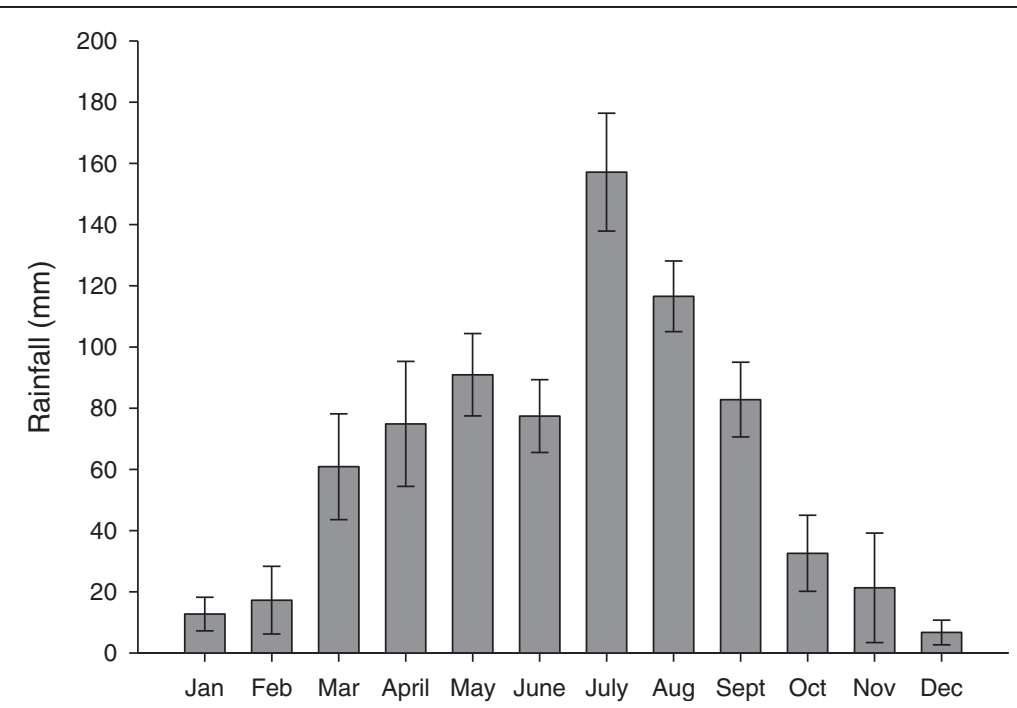

Fig. 2 Mean monthly rainfall of the study area in the past 10 years 


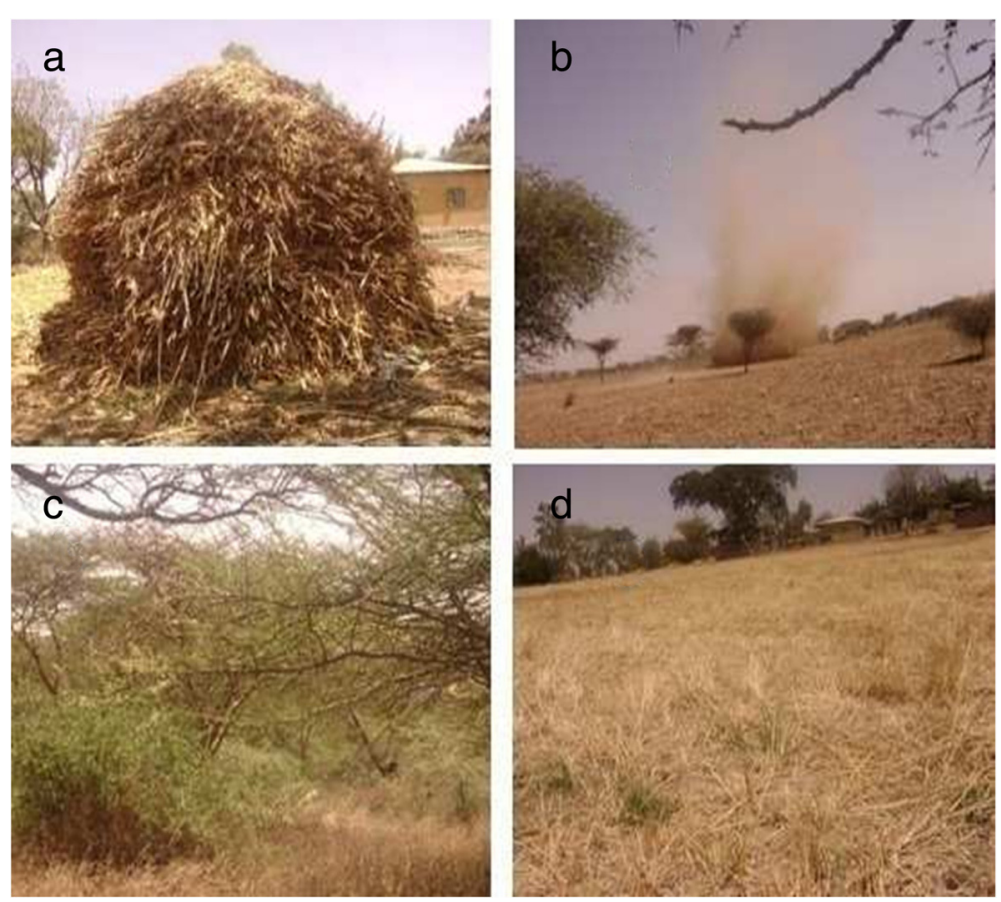

Fig. 3 Farming system in the study area, showing piled maize Stover collected from TLCL and PAF for animal feed (a), wind erosion in the study area (b), the PWL composition (c) and the Rhodes grass straw in MPL (d)

days, and carefully added to nests of sieves, with a pan underneath, having $2 \mathrm{~mm}, 1 \mathrm{~mm}, 0.5 \mathrm{~mm}, 0.25$, and $0.053 \mathrm{~mm}$ size arranged from top to bottom, respectively, on the shaker apparatus. Each sample was added to the top sieve and subjected to shaking for $30 \mathrm{~s}$ (Hao et al. 2008). The remained fraction on each sieve was weighed using sensitive digital balance.

\section{Measurements, calculations and data analysis}

The percent aggregate fraction was calculated following Lal and Shukla (2006) as follows:

$$
\begin{aligned}
\% \text { Aggregate on } \mathrm{X}_{\mathrm{i}}= & \left(\mathrm{W}_{\mathrm{xi}}-\mathrm{W}_{\mathrm{sxi}} / \mathrm{W}_{\mathrm{tss}}-\mathrm{W}_{\mathrm{st}}\right) \\
& \times 100
\end{aligned}
$$

Where $X$ stands for sieve size and $i$ is from 1-6 (representing the fraction sizes considered for this study), $W_{x i}$ is weight of soil retained on $X_{i}$, $W_{s x i}$ is weight of sand fraction on $X_{i}, W_{t s s}$ is total soil sample, and $W_{s t}$ is sand fraction in total soil sample.

Geometric Mean Diameter (GMD) and Mean Weight Diameter (MWD) were the two dry aggregate stability indices calculated as described in Lal and Shukla (2006).

$$
\text { GMD }=\operatorname{Exp} \sum_{i=1}^{6} \text { ri log di }
$$

$$
\mathrm{MWD}=\sum_{\mathrm{i}=1}^{6} \text { ridi }
$$

Where: GMD is Geometric Mean Diameter, $M W D$ is Mean Weight Diameter, $i$ is the aggregate classes $(>2,2-$ $1,1-0.5,0.5-0.25,0.25-0.053$ and $<0.053), r i$ is the ratio of aggregate mass of each class to the total aggregates, and $d i$ is the mean diameter for class $i$. Total Porosity was calculated using BD and Particle Density (PD) as described in Hao et al. (2008).

$$
\mathrm{P}=1-(\mathrm{BD} / \mathrm{PD}) \times 100
$$

Where, $P$ is total porosity, $B D$ is bulk density and $P D$ is particle density.

Data were subjected to two way Analysis of Variance (ANOVA) using SAS version 9 (SAS Institute 2002). Tukey's HSD mean separation technique was employed to separate means, where significant difference $(\mathrm{p}<0.05)$ was found between means.

\section{Results and discussion}

\section{Soil texture}

The difference in the proportion of sand content among the different land uses was statistically significant $(\mathrm{P}<0.001)$. The highest proportion was observed under TLCL and PAF (58.3\%, Table 1) whereas; the lowest sand proportion was recorded under PWL, followed by MPL. However, silt 
and clay contents were found to be similar among the land uses. The overall textural class of the soil under the different land uses was sandy loam (Table 1).

In this study, the observed similar textural class of soil under the different land uses minimized differences in soil physical and chemical properties that could have been observed due to the difference in soil texture. Therefore, it is more likely that differences in soil physical and chemical properties among the different land uses in the study area could be due to other land use change and land management factors.

\section{Dry aggregate stability}

\section{Soil dry aggregate stable size distribution}

Percent soil dry aggregate stable size distribution (DASD) under the four land uses was very highly different $(\mathrm{p}<$ 0.001 ) at aggregate size classes of $>2,0.5-1,0.25-0.5$ and $<1 \mathrm{~mm}$ (Fig. 4). However, there was no difference in aggregate size classes of $12,0.0530 .25$ and $<0.053 \mathrm{~mm}$ under the four land use/cover types. Dry aggregate fraction of $>$ $2 \mathrm{~mm}$ was higher under PWL and MPL than PAF and TLCL. On the other hand, DASD $<1 \mathrm{~mm}$ was lower under PWL and MPL than PAF and TLCL (Fig. 4).

Macro-aggregate class $(>0.25 \mathrm{~mm})$ was higher $(\mathrm{P}<0.001)$ under MPL (73.7 \%) and PWL (72.6 \%) as compared to PAF and TLCL (Fig. 4). On the other hand, microaggregate class $(0.053-0.25)$ was higher under TLCL (35.4 $\%)$ followed by PAF (27.6\%). Macro-aggregates are reported to contain higher amount of SOC and $\mathrm{N}$ over micro-aggregates (Jiao et al. 2006).

On the other hand, macro-aggregates are more prone to management (Ashagrie et al. 2007) than microaggregates which are relatively stable. The result of this study could imply that the higher sensitivity of soil under PWL and MPL to abrupt loss of aggregate stability if they are converted to TLCL and PAF.

Land use type affects soil wind erodiblity by affecting percent DASD. Resistance to wind erosion of soil, has been evaluated towards the percent DASD of $\geq 0.84 \mathrm{~mm}$ (Chepil 1952; Lyles and Tatarko 1988; Díaz-Zorita et al. 2002; Greeves et al. 2007), and aggregates less than 0.84 $\mathrm{mm}$ are highly susceptible to wind erosion; whereas, those above this range are less susceptible to wind erosion. However, Woodruff and Siddoway (1965) found that soil aggregates $<1 \mathrm{~mm}$ are also potentially erodible by wind, of which the micro-aggregates $(0.05-0.25 \mathrm{~mm})$ are the most erodible soil fraction (Yang et al., 2007). Therefore, this implies soil under TLCL and PAF is potentially more erodible than soil under PWL and MPL. This could be attributed to the lands under TLCL and PAF have been tilled for more than 25 years continuously, crop residues are removed and mono-cropping is practiced under these land use types. Thus, these might have lost aggregate forming substances such as organic matter (OM).

Intensive grazing (de Souza et al. 2010), absence of tillage (PWL) and periodic tillage (MPL) resulted in lower fraction of soil that are potentially susceptible to wind erosion (Masri and Ryan 2006). The higher organic matter from litter-falls, root death of the Acacia trees and absence of tillage under the PWL enhanced fraction of coarse aggregates. In case of the MPL, however, the result could be attributed to the existence of Rhodes grass straw and the less tillage frequency on the land use (Børresen 1999). This could also be attributable to the existence of high SOC, moisture content and porosity that might have created suitable environment for microorganisms such as the arbuscular mycorrhizal fungi, which of their hyphae might have created strong binding effect (Hartmann, 2008). Wilson et al. (2009) conducted long term experiment at the Konza Prairie Biological Station, Kansas, and found that there was strong relationship between aggregation stability, SOC and $\mathrm{N}$ sequestration, and abundance of arbuscular mycorrhizal fungi.

\section{Geometric mean diameter and mean weight diameter}

Both GMD and MWD under PWL and MPL were higher $(\mathrm{P}<0.001)$ than that of PAF and TLCL (Fig. 5). This implies that, soil under PWL and MPL was relatively more stable, and less susceptible to wind erosion than PAF and TLCL. GMD was strongly associated $\left(\mathrm{R}^{2}=0.71\right)$ with SOC (Fig. 6). The higher GMD of soil under PWL and MPL could therefore be associated to the relatively higher respective SOC concentration under these land uses.

Table 1 Soil pH and textural class of the land use and land cover types considered for the study

\begin{tabular}{llllll}
\hline Land use & $\mathrm{pH}$ & \% sand & \% silt & \% clay & Textural class \\
\hline TLCL & $7.5(0.1) \mathrm{a}$ & $58.3(0.8) \mathrm{a}$ & $28.1(0.8) \mathrm{a}$ & 13.7 (0.6)a & Sandy loam \\
MPL & $7.0(0.1) \mathrm{a}$ & $53.5(0.6) \mathrm{b}$ & $30.8(1.6) \mathrm{a}$ & $16.3(1.0) \mathrm{a}$ & Sandy loam \\
PWL & $7.1(0.1) \mathrm{a}$ & $54.3(0.3) \mathrm{b}$ & $31.3(0.6) \mathrm{a}$ & $14.0(0.6) \mathrm{a}$ & Sandy loam \\
PAF & $7.0(0.1) \mathrm{a}$ & $58.3(0.5) \mathrm{a}$ & $27.5(0.9) \mathrm{a}$ & $14.3(0.6) \mathrm{a}$ & Sandy loam \\
\hline
\end{tabular}

Values indicated by different letters across the land uses, along the column, are statistically different $(p<0.001)$. Numbers in the parenthesis are standard errors $(n=3) . P W L=$ protected woodland, $\mathrm{MPL}=$ managed pastureland, $\mathrm{PAF}=$ parkland agroforestry, $\mathrm{TLCL}=$ treeless cropland 


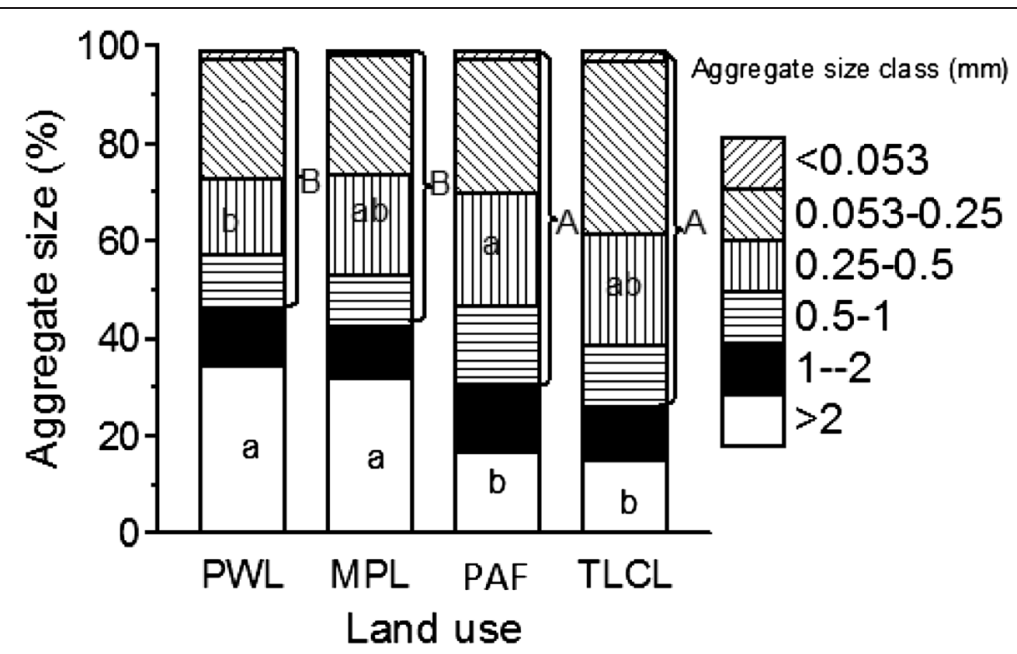

Fig. 4 Soil aggregate size class distribution to $15 \mathrm{~cm}$ depth under the four land uses. Bars with different letters with similar texture across the different land uses are significantly different $(P<0.001 ; n=3)$. Bars indicated by different letters are significantly different at $P<0.001$ across the different land uses. PWL = protected woodland, MPL = managed pastureland, PAF = parkland agroforestry, $\mathrm{TLCL}=$ treeless cropland

Bulk density, total porosity and moisture content

Soil under TLCL has got the highest BD, followed by the PAF. In all land use types, the highest soil BD was observed in the upper soil depth range, $0-15 \mathrm{~cm}$, followed by the $15-30 \mathrm{~cm}$ depth. The least soil BD was observed in the 30-45 depth range (Fig. 7).

In the study area, free grazing is very common, and this might have caused trampling effect, and that might be accounted for the increase in soil BD in the upper soil layer. Animal trampling effect in most cases resulted in high BD (Proffitt et al. 1993, 1995; Chaichi et al. 2005; Bell et al. 2011). Chaichi et al. (2005) found similar result in Lar rangeland of Iran, and reported higher BD in the top $0-15 \mathrm{~cm}$ depth than the $15-30 \mathrm{~cm}$. The lowest soil BD was observed in the top $0-15 \mathrm{~cm}$ under MPL, when compared to the other three land uses. This could be attributable to pasture under MPL is protected from direct grazing by cattle, and the grass is used in a cut and carry system.

Increase in BD reduces soil quality in such a way that it affects associated soil parameters such as soil infiltration, porosity and moisture content thereby reducing crop productivity at large (Bell et al. 2011). Soil with high BD enhances erosion and limits optimum crop root growth which in turn has negative impact on total plant's biomass production and yield. Therefore, in order to sustain soil productivity, protecting the land from free grazing and appropriate crop residue management should be taken in to account.

Gravimetric soil moisture content (MC) was significantly higher $(\mathrm{P}<0.001)$ under $\mathrm{PWL}$ and $\mathrm{MPL}$ than PAF and TLCL (Fig. 7). This may be attributable to the presence of trees and shrub in the PWL, and the presence of straw on the MPL that covers the soil

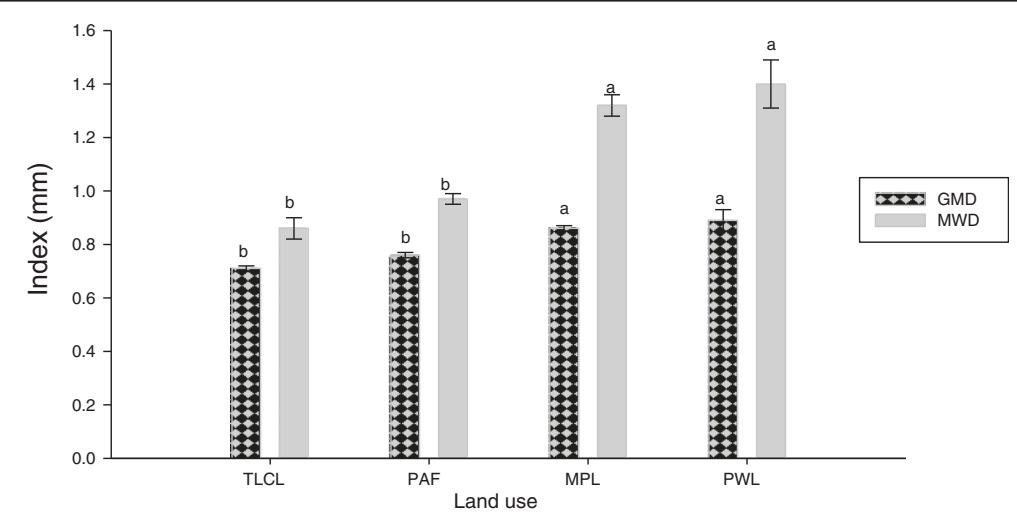

Fig. 5 Geometric Mean Diameter (GMD) and Mean Weight Diameter (MWD) across the different land uses. Bars indicated by different letters are significantly different at $\mathrm{p}<0.001$ across the different land uses. PWL = protected woodland, MPL = managed pastureland, PAF $=$ parkland agroforestry, $\mathrm{TLCL}=$ treeless cropland 


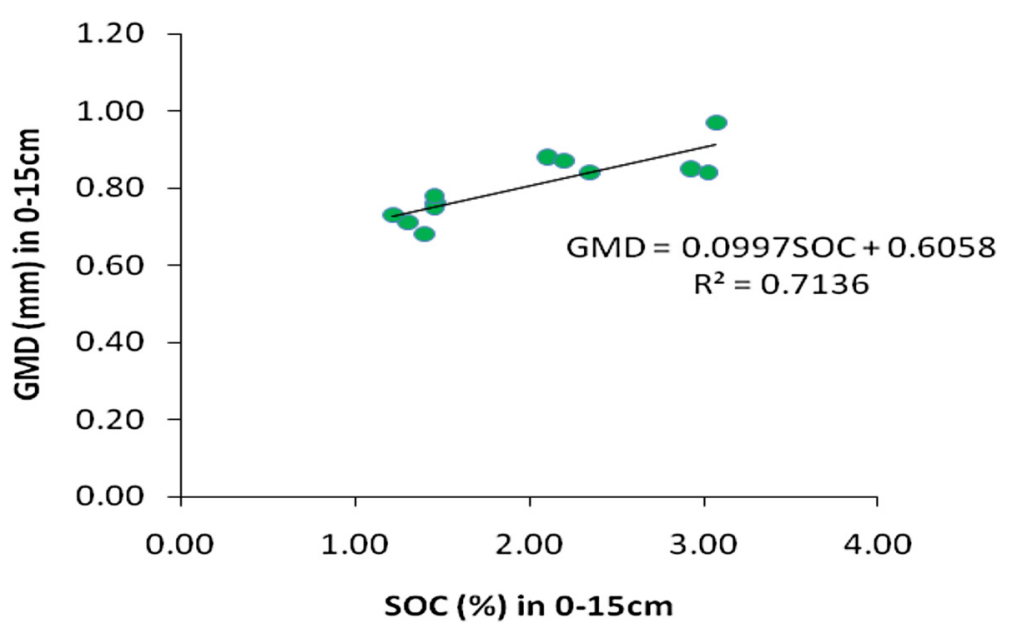

Fig. 6 GMD as a function of SOC concentration. SOC data were used from Biyensa (2011, unpublished) Status of soil properties under different land use/land cover types in Adami Tulu, MSc thesis, Hawassa University, College of Agriculture

from direct sun-light and which keeps the soil cool (Lal 2004). Børresen (1999) compared different straw managements such as chopping, direct incorporation, burning and removing on soil physical and chemical properties and found that a straw cover maintained soil moisture and increased crop yield during the dry seasons.
The relatively higher MC content in MPL than PWL may be due to the impact of the incorporated Rhodes grass straw and the addition of $\mathrm{N}$ and $\mathrm{P}$ containing fertilizers to the MPL to enhance biomass production of the Rhodes grass. Zeleke et al. (2004) found that incorporating residue with fertilizer, in CRV of Ethiopia, improved soil properties when compared to application of crop residue alone. The

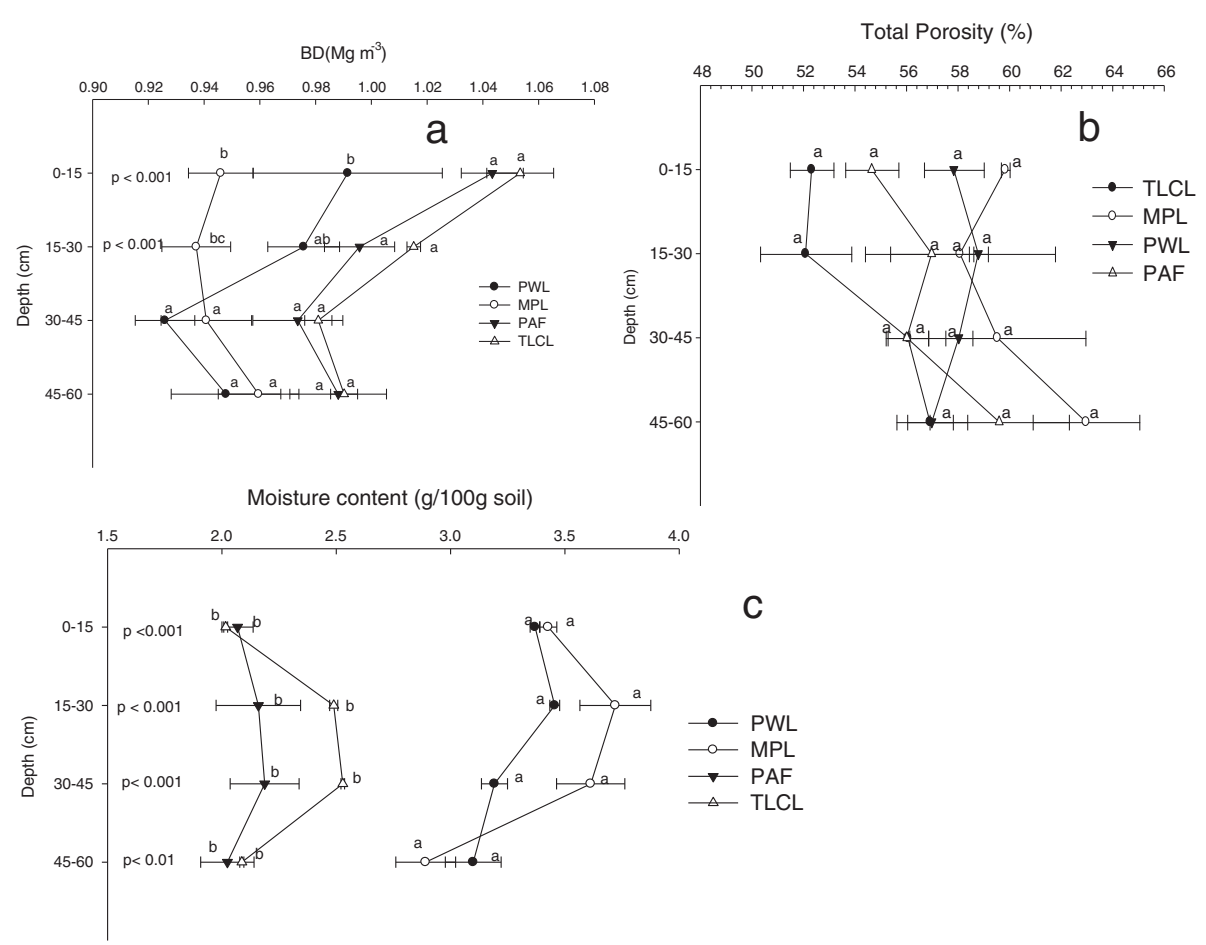

Fig. 7 Graph showing trends of soil bulk density (a), total porosity (b) and gravimetric moisture content (c) from surface to down subsurface layers. Points indicated with the same letter across the land uses with the respective prescribed depth range are not statistically significant $(\mathrm{P}<0.001) . \mathrm{PWL}=$ protected woodland, $\mathrm{MPL}=$ managed pastureland, $\mathrm{PAF}=$ parkland agroforestry, $\mathrm{TLCL}=$ treeless cropland 
highest soil mean porosity under MPL may be attributed to the relatively lower animal trampling in the MPL. The relatively more porosity of soil under MPL as compared to the PAF and TLCL could be also owing to the contribution of the organic matter added to the soil from Rhodes grass straw and root (Børresen 1999; Singh et al. 2005).

\section{Conclusion}

Land degradation in CRV of Ethiopia is frequently reported to be severe, and has been negatively affecting the ecosystem. The need for extra land for agriculture by farmers in the area is posing pressure on Acacia woodlands. Farmers are converting these woodlands to cultivated lands. Subsequently, these evolved cultivated lands are used to grow mainly a single crop for many years. Since feed shortage is so severe, due to the long drought season in the area, farmers almost totally remove the crop residues and feed their cattle or sell it to the nearby semi-urban small dairy farms, keeping the soil bare. This has negative impact on the soil organic matter thereby disrupting the aggregate stability of soil. It has been so common to see severe soil wind erosion in the area during the dry season. This study was therefore aimed at evaluating some soil properties effect on indicators for soil wind erosion in this rift valley. Soil aggregate stability significantly decreased following conversion of native Acacia woodland to conventional cultivated lands such as the TLCL and PAF. This could be associated with the loss of SOC under the respective land uses. In all land use types considered, animal free grazing caused trampling effect thereby increasing soil bulk density in the top 0-15 cm. In the study area, loss of soil moisture, lower porosity and higher bulk density were highly pronounced under TLCL and PAF than under MPL and PWL.

\section{Competing interests}

The authors declare that they have no competing interests.

\section{Authors' contributions}

BG initiated, proposed, collected data and analyzed. He also prepared a draft manuscript for publication. AD assisted in designing, data collection and analysis and reviewed the manuscript and edited many times and added his inputs. Finally, BL also supported in designing the research proposal and data collection procedure. He also edited the manuscript and included his own inputs for the betterment of the paper. All authors approved the paper for publication.

\section{Authors' information}

Biyensa Gurmessa is Research Officer at International Center for Tropical Agriculture (CIAT). Ambachew Demissie (PhD) is assistant professor at Hawassa University College of Agriculture. Bekele Lemma, Chemistry Department, Hawassa University.

\section{Acknowledgements}

The authors would like to thank the Rural Capacity Building Project for funding the study. Laboratory technicians of the Zeway soil testing laboratory are also duly acknowledged for unreserved assistance during the soil sample preparation and analysis. Finally, the authors are also very grateful to the anonymous reviewers who forwarded their invaluable comments on the manuscript.

\section{Author details}

'International Center for Tropical Agriculture (CIAT), clo International Livestock Research Institute (ILRI), Addis Ababa office, Addis Ababa, Ethiopia. ${ }^{2}$ Hawassa University College of Agriculture, Hawassa, Ethiopia. ${ }^{3}$ Bekele Lemma, Chemistry Department, Hawassa University, Shashemane, Ethiopia.

Received: 19 March 2015 Accepted: 7 May 2015

Published online: 29 May 2015

\section{References}

Alberti G, Vedove GD, Zuliani M, Peressotti A, Simona CS, Giuseppe ZG (2010) Changes in $\mathrm{CO}_{2}$ emissions after crop conversion from continuous maize to alfalfa. Agric Ecosyst Environ 136:139-147

Ashagrie Y, Zech W, Guggenberger G, Taye M (2007) Soil aggregation, and total and particulate organic matter following conversion of native forests to continuous cultivation in Ethiopia'. Soil Tillage Res 94:101-108

Bell LW, Kirkegaard JA, Swan A, Hunt JR, Huth NI, Fettell NA (2011) Impacts of soil damage by grazing livestock on crop productivity. Soil Tillage Res 113:19-29

Binkley D, Singer F, Kayea M, Rochellea R (2003) Influence of elk grazing on soil properties in Rocky Mountain National Park. For Ecol Manage 185:239-247

Biyensa (2011, Unpublished) Status of soil properties under different land use/ land cover types in Adami Tulu, MSc thesis, Hawassa University, College of Agriculture, $\mathrm{p} 81$.

Børresen T (1999) The effect of straw management and reduced tillage on soil properties and crop yields of spring-sown cereals on two loam soils in Norway. Soil Tillage Res 51:91-102

Chaichi MR, Saravi MM, Malekian A (2005) Effects of livestock trampling on soil physical properties and vegetation cover (Case Study: Lar Rangeland, Iran). Int J Agric Biol 6:904-908

Chepil WS (1952) Improved rotary sieve for measuring state and stability of Dry soil structure. Soil Sci Soc Am Proc 16:113-117

Curran-Cournane F, McDowell RW, Littlejohn R, Condron LM (2010) Effects of stock type on soil physical properties and losses of phosphorus and suspended sediment in surface runoff. In: $19^{\text {th }}$ World Congress of Soil Science, Soil Solutions for a Changing World 1 - 6 August 2010, Brisbane, Australia

De Souza ED, de Andrade G, Costa SEV, Anghinoni I, de Faccio CPC, de Oliveira EVF, Martins AP, Cao E, Andrighetti M (2010) Soil aggregation in a crop-livestock integration system under no-tillage. Revista Brasileira De Ciencia Do Solo 34:1365-1374

Díaz-Zorita M, Grove JH and Perfect E (2002) Aggregation, fragmentation, and structural Stability measurement. In: Lal R (ed) Encyclopedia of soil science. New York, p 37-40.

Gajic B, Tapanarova A, Tomic Z, Kresovic B, Vujovic D, Pejic B (2013) Land use effects on aggregation and erodibility of Luvisols on undulating slopes. AJCS 7(8):1198-1204

Getachew E, Ståhl G (1998) Functions for multi-phase assessment of biomass in acacia woodlands of the Rift Valley of Ethiopia. For Ecol Manage 105:79-90

Greeves GW, Leys JF, McTainsh GH (2007) Soil erodibility. In: Charman PEV, Murphy BW (eds) Soils - their properties and management. Oxford University Press, Melbourne, pp 206-221

Hamza MA, Anderson WK (2005) Soil compaction in cropping systems. A review of the nature, causes and possible solutions. Soil Tillage Res 82:121-145

Hao X, Ball BC, Culley JLB, Carter MR, Parkin GW (2008) Soil density and porosity. In: Carter MR, Gregorich EG (eds) Soil sampling and methods of analysis. Taylor \& Francis Group, LLC, U.S.A, pp 743-760

Hartmann R (2008) Aggregation. In: Chesworth W (ed) Encyclopedia of soil science. Springer, The Netherlands, pp 30-33

Itanna F (2005) Sulfur distribution in five Ethiopian Rift Valley soils under humid and semi- arid climate. J Arid Environ 62:597-612

Jansen H, Hengsdijk H, Dagnachew L, Ayenew T, Hellegers P, Splietoff P (2007) Land and water resources assessment in the Ethiopian CRV. In: Project: ecosystems for water, food and economic development in the Ethiopian CRV, Alterra rapport. Wageningen University, the Netherlands

Jiao Y, Whalen JK, Hendershot WH (2006) No-tillage and manure applications increase aggregation and improve nutrient retention in a sandy-loam soil. Geoderma 134:24-33

Lal R (2004) Carbon sequestration in dry land ecosystems. Environ Manage 33:528-544

Lal R, Shukla MK (2006) Principles of soil physics. Marcel Dekker, New York 
Liu X, Herbert SJ, Hashemi AM, Zhang X, Ding G (2006) Effects of agricultural management on soil organic matter and carbon transformation - a review. Plant Soil Environ 52(12):531-543

Lyles L, Tatarko J (1988) Soil wind erodibility index in Seven North Central States. ASAE 31(5):1396-1399

Martínez LJ, Zinck JA (2004) Temporal variation of soil compaction and deterioration of soil quality in pasture areas of Colombian Amazonia. Soil Tillage Res 75:3-17

Masri Z, Ryan J (2006) Soil organic matter and related physical properties in a Mediterranean wheat-based rotation trial. Soil Tillage Res 87:146-154

Osunbitana JA, Oyedeleb DJ, Adekalu KO (2005) Tillage effects on bulk density, hydraulic conductivity and strength of a loamy sand soil in southwestern Nigeria. Soil Tillage Res 82:57-64

Proffitt AP, Bendotti S, Howell MR, Eastham J (1993) The effect of sheep trampling and grazing on soil physical properties and pasture growth for a red-brown earth. Aust J Agr Res 44:317-331

Proffitt APB, Bendotti S, McGarry D (1995) A comparison between continuous and controlled grazing on a red duplex soil. I. Effects on soil physical characteristics. Soil Tillage Res 35:199-210

Quirogaa AR, Buschiazzoa DE, Peinemann N (1999) Soil compaction is related to management practices in the semi-arid Argentine pampas. Soil Tillage Res $52: 21-28$

Radford BJ, Yule DF, Braunack M, Playford C (2008) Effects of grazing sorghum stubble on soil physical properties and subsequent crop performance. Am J Agric Biol Sci 3(4):734-742

Rouw A, Huon S, Soulileuth B, Jouquet P, Pierret A, Ribolzi O, Valentin C, Bourdon E, Chantharath B (2010) Possibilities of carbon and nitrogen sequestration under Conventional tillage and no-till cover crop farming (Mekong valley, Laos). Agric Ecosyst Environ 136:148-161

SAS Institute (2002) SAS/FSP 9 Procedures Guide. SAS Institute Inc, Cary, NC, USA Sharrow SH (2007) Soil compaction by grazing livestock in silvopastures as evidenced by changes in soil physical properties. Agroforestry Syst 71:215-223

Singh G, Jalota SK, Sidhu BS (2005) Soil physical and hydraulic properties in a rice-wheat cropping system in India: effects of rice-straw management. Soil Use Manage 21:17-21

Siri-Prieto G, Reeves DW, Raper RL (2007) Tillage systems for a cotton-peanut rotation with winter-annual grazing: impacts on soil carbon, nitrogen and physical properties. Soil Tillage Res 96:260-268

Snyder CS, Bruulsema TW, Jensen TL, Fixen PE (2009) Review of greenhouse gas emissions from crop production systems and fertilizer management effects. Agric Ecosyst Environ 133:247-266

Wilson GWT, Rice CW, Rilling MC, Springer A, Hartnett DC (2009) Soil aggregation and carbon sequestration are tightly correlated with the abundance of arbuscular mycorrhizal fungi. Ecol Lett 12:452-461

Woodruff NP, Siddoway FH (1965) A wind erosion equation. Soil Sci Soc Am Proc 29:602-608

Yang S, Lianyou L, Ping Y, Tong C (2007) A review of soil erodibility in water and wind erosion research. J Geogr Sci 15(2):167-176

Yimer $\mathrm{F}$ and Abdelkadir A (2010) Soil property changes following conversion of Acacia woodland into grazing and farmlands in the rift valley area of Ethiopia. Land Degradation Dev. doi:10.1002/ldr.1022.

Zeleke TB, Grevers MCG, Si BC, Mermuta AR, Beyene S (2004) Effect of residue incorporation on physical properties of the surface soil in the South CRV of Ethiopia. Soil Tillage Res 77:35-46

Zewdie E (2004) Characterization and genesis of some soils of the Ethiopian Rift Valley Showing andic properties. Ethiop J Nat Resour 6:215-235

\section{Submit your manuscript to a SpringerOpen ${ }^{\circ}$ journal and benefit from:}

- Convenient online submission

- Rigorous peer review

- Immediate publication on acceptance

- Open access: articles freely available online

- High visibility within the field

- Retaining the copyright to your article

Submit your next manuscript at $\gg$ springeropen.com 